\title{
VEZDAEA RETIGERA (VEZDAEACEAE), A FACULTATIVELY EPIBRYOPHYTIC LICHENIZED FUNGUS NEW TO HUNGARY
}

\author{
Csaba NÉMETH ${ }^{1}$ and Jan ECKSTEIN ${ }^{2}$ \\ ${ }^{1}$ GINOP Sustainable Ecosystems Group, MTA Centre for Ecological Research, \\ H-8237 Tihany, Klebelsberg Kuno út 3, Hungary; nemetcsaba@gmail.com \\ ${ }^{2}$ Heinrich-Heine-Str. 9, DE-37083 Göttingen, Germany; jan.eckstein@octospora.de
}

Németh, Cs. \& Eckstein, J. (2017): Vezdaea retigera (Vezdaeaceae), a facultatively epibryophytic lichenized fungus new to Hungary. - Studia bot. hung. 48(2): 41-46.

Abstract: Vezdaea retigera, a lichenized fungus often growing on the gametophyte of various moss species, on thalli of the lichen Peltigera and also on soil was first observed in Hungary in the Börzsöny, Bükk and Zemplén Mts. The Hungarian finds are described in detail and illustrated with various macro- and micrographs.

Key words: epibryophytic, goniocyst, lichenized fungi

\section{INTRODUCTION}

Vezdaeaceae Poelt et Vězda ex J. C. David et D. Hawksw. is a monotypic family including a single genus Vezdaea Tscherm.-Woess et Poelt that comprises 12 species of lichenized fungi. Eight of them, $V$. acicularis Coppins, $V$. aestivalis (Ohlert) Tscherm. Woess et Poelt, V. cobria Giralt, Poelt et Suanjak, V. dawsoniae Döbbeler, $V$. leprosa (P. James) Vězda, $V$. retigera Poelt et Döbbeler, $V$. rheocarpa Poelt et Döbbeler, as well as V. stipitata Poelt et Döbbeler occur in Europe (GIrALT et al. 1993). All of them are comparatively inconspicuous lichens forming thalli composed of corticate granules (goniocysts). The mostly minute apothecia are only formed in prolonged wet periods. Because of the inconspicuous thalli and ephemeral presence of apothecia species of Vezdaea are often overlooked.

\section{MATERIAL AND METHODS}

Geographical coordinates were determined using a Garmin eTrex Legend GPS. Specimens were deposited in the private collection of the first author and the lichen herbarium of BP (Hungarian Natural History Museum, Budapest, Hungary). Most of the microscopical observations were made on samples in tap water, but paraphyses were studied after staining with Lactophenol Cotton Blue. 
For macrographs a Canon D1000 camera with Canon EF $100 \mathrm{~mm}$ F/2.8 Macro USM objective were used. Micrographs were taken with a Zeiss AxioCam HRc digital camera attached to a Zeiss Axio Imager A2 research microscope. Spore size and other microscopical quantitative characters were measured by means of AxioVision 4.8.2 microscope software. Abbreviation 'FCsN' refers to the private fungarium of the author. New Hungarian occurrence was displayed in a grid-cell map based on the Central European Mapping Scheme ('KEF', 5 ' $\times$ $\left.3^{\prime}=c a 5.5 \times 6.5 \mathrm{~km}\right)$.

\section{RESULTS AND DISCUSSION}

During a bryological field trip conducted in the Börzsöny Mts, Hungary, numerous whitish, hemispherical apothecia accompanied by granulated algae were encountered growing abundantly on and among shoots of the moss Weissia controversa (Fig. 1a). The collected material was later identified as Vezdaea retigera, which proved to be new to the Hungarian lichen flora. Later it turned up in the Bükk and Zemplén Mts as well (Fig. 1b).

\section{Specimens examined}

Hungary, Börzsöny Mts, Hálás-bérc above Pokol Valley, FCsN 7923, ca $47.90772^{\circ} \mathrm{N} 18.92050^{\circ} \mathrm{E}$, ca $620 \mathrm{~m}, 01.04 .2016$, with Weissia controversa on a nearly vertical bank along a forest track, on soil overlying dacite tuff bedrock, leg. Cs. Németh (accompanied by P. Erzberger, A. Kovács, J. Nagy, B. Papp and A. Rigó), det. J. Eckstein [8079.4].

Hungary, Zemplén Mts, Nagy-Vadász-tető above Rostalló, $48.42306^{\circ} \mathrm{N}$ $21.40917^{\circ} \mathrm{E}$, ca $400 \mathrm{~m}, 16.04 .2017$, slope of forest track, leg./det. J. Eckstein (without specimen) [7594.3].

Hungary, Bükk Mts, near spring Eszperantó above Lake Hámor, FCsN 9389, ca $48.11078^{\circ} \mathrm{N} 20.60942^{\circ} \mathrm{E}$, ca $368 \mathrm{~m}, 04.04 .2018$, with Barbula convoluta along a forest track, leg. Cs. Németh and P. Erzberger, det. Cs. Németh [7889.4].

\section{Description}

Thalli are composed of greyish green to dark green goniocysts (photosymbiont belongs to the genus Leptosira) (Fig. 1c-e) with short spines up to $2 \mu \mathrm{m}$ (Fig. 1f). Apothecia hemispherical, $0.2-0.5(-0.6) \mathrm{mm}$ in diameter (Fig. 1c-e), asci $110-120(-150) \mu \mathrm{m}$ long and $20-24(-29) \mu \mathrm{m}$ wide at the widest part, containing 8 ascospores arranged uni- to biseriately (Fig. 1g). Paraphyses long, intimately entwining individual asci (Fig. 1h). Spores simple, ellipsoid, smooth 17-22 $\times$ 9-11 $\mu \mathrm{m}$ with many small droplets almost filling the spore lumen (Fig. 1i). 

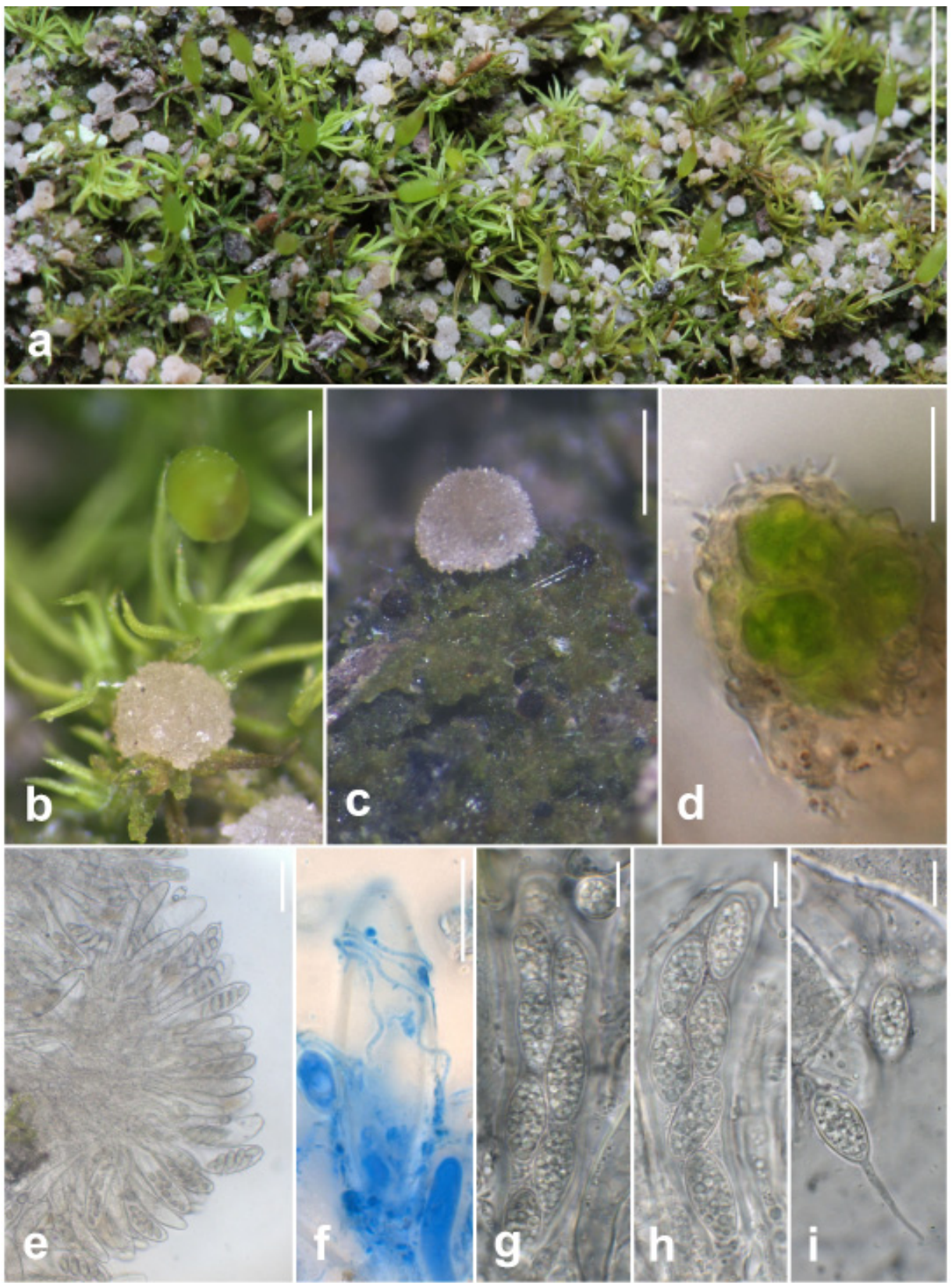

Fig. 1. Vezdaea retigera. $-\mathrm{a}=$ Greenish granular thallus and whitish hemispherical apothecia on and among shoots of Weissia controvers $a .-\mathrm{b}=$ Greenish granular thallus and whitish hemispherical apothecia on and among shoots of Barbula convoluta. $-\mathrm{c}, \mathrm{d}=$ Hemispherical ascomata and granular goniocysts growing on leaves of $W$. controvers $a$ and the surrounding soil surface. $-\mathrm{e}=$ Hemispherical ascomata and granular goniocysts growing on leaves of $B$. convoluta. $-\mathrm{f}=$ Structure of a goniocyst with spiny surface. $-\mathrm{g}=$ Structure of an ascomata composed solely of the hymenium. $-\mathrm{h}=$ Paraphyses entwining an ascus (stained with Lactophenol Cotton Blue). $-\mathrm{i}=$ Ascus with ascospores; scale bars $\mathrm{a}-\mathrm{b}=5 \mathrm{~mm}, \mathrm{c}-\mathrm{e}=0.5 \mathrm{~mm}, \mathrm{f}=10 \mu \mathrm{m}, \mathrm{g}=50 \mu \mathrm{m}, \mathrm{h}-\mathrm{i}=10 \mu \mathrm{m}$. (Photos by Cs. Németh). 


\section{Ecology}

Vezdaea retigera is an ephemeral lichenised fungus predominantly found as muscicolous or lichenicolous species growing on various terricolous bryophytes and Peltigera sp. (Alstrup et al. 2004, Chambers and Purvis 2009, Czarnota and KuKWA 2009, PALICE 1999), but also growing directly on mineral soil in different types of habitats. $V$. retigera develops mature ascomata mainly during winter and spring (CoppINs 1987). In Western Europe and North America it is considered to be a toxitolerant species occurring in metal-enriched habitats on baserich grounds, in post-mining areas or on waste heaps (CHAMbERs and PURVIS 2009). In Sweden it was collected on calcareous rocks in an abandoned quarry (Svensson and Westberg 2010). In Poland it was found on calcareous substrates, sand dune and granite boulders as well (CZARNotA and KuKWA 2009). In Hungary it was found on rather acidic soil developing on dacite tuff bedrock (GYALOG and Sí KHEgYi 2005) in the Börzsöny Mts , on mixed badrock composed of sandstone, limestone and marl in the Bükk Mts, and on intermediate soil on the slope of a forest track overlying rhyolite tuff bedrock in the Zemplén Mts.

\section{Distribution}

Vezdaea retigera is a circumpolar species widely distributed throughout the Northern Hemisphere. It was reported from North America (Lendemer and YAHR 2004) and various European countries (Alstrup et al. 2004, Aptroot et al. 2004, Clauzade and Roux 1985, Coppins 1987, Diederich et al. 2006, Kocourková 2000, PyкÄlä 2006, Santesson et al. 2004, Scholz 2000, Smith et al. 2009, Stepanchikova et al. 2011, Svensson and Westberg 2010, Svoboda 2007, TÜrk and Berger 1999, Wirth et al. 2013). The new occurrences in the Börzsöny and Zemplén Mts represent its first Hungarian observations (Fig. 2; LöKös and FARKAS 2009, VerSEGHY 1994). Due to its inconspicuous habit and small ascomata developing characteristically in winter when field activity of lichenologists is quite moderate, $V$. retigera is probably an often overlooked species and may be underrepresented in lichen collections.

\section{Differentiating from similar taxa}

Vezdaea retigera differs from most of its congeners in having simple rather than septate spores, a trait shared only with $V$. rheocarpa within the whole genus. The latter, however, has distinctive verrucose spores (smooth in V. retigera), shorter and free paraphyses (entwining individual asci in $V$. retigera) and longer spines on goniocysts (4-15 $\mu \mathrm{m}$ contrary to up to $2 \mu \mathrm{m}$ in $V$. retigera). 


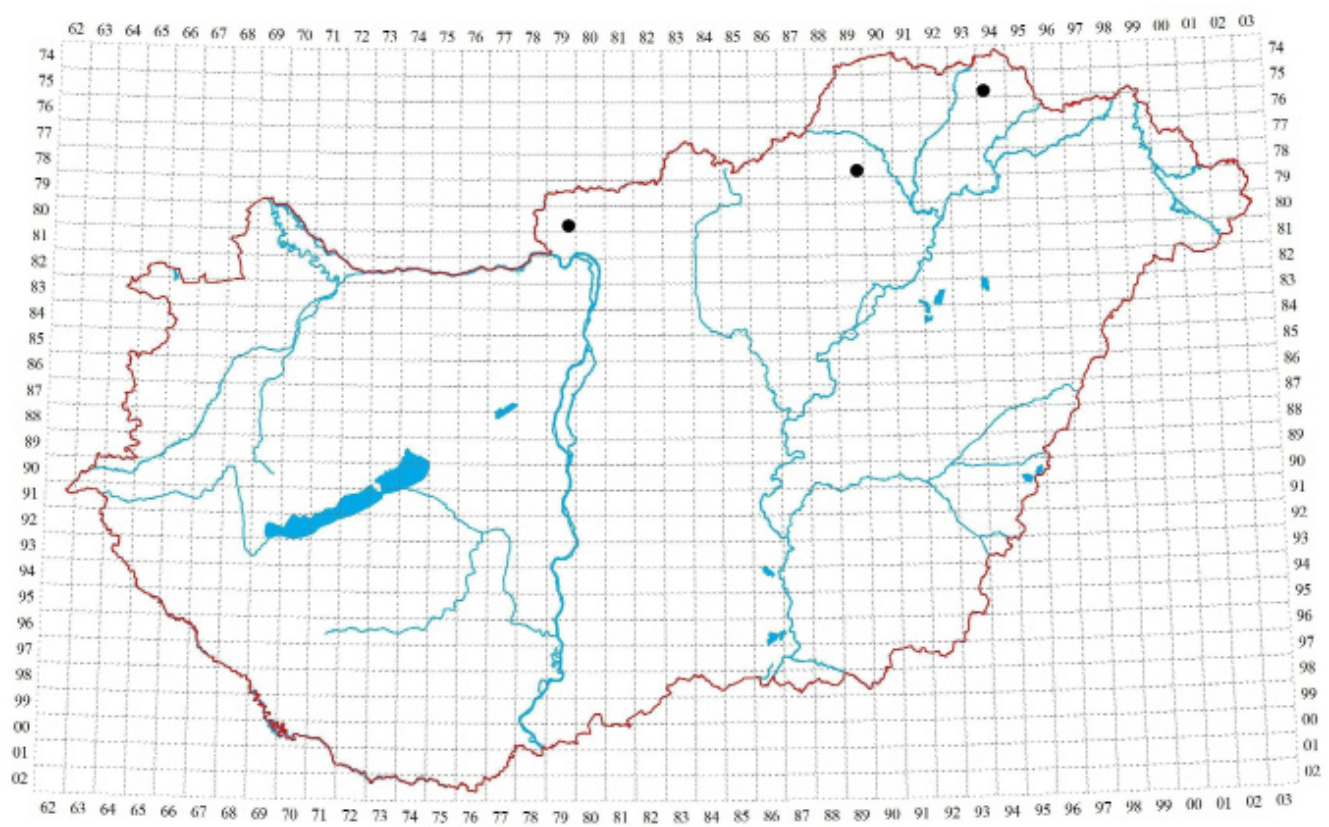

Fig. 2. Occurrences of Vezdaea retigera in Hungary.

Acknowledgements - We would like to thank László Lőkös (Hungarian Natural History Museum) for confirming the identification of the specimen collected in the Börzsöny Mts and Peter Erzberger for organising an excursion to the Zemplén Mts.

Összefoglaló: A Vezdaea retigera cirkumpoláris elterjedésű, efemer karakterű, aszkómáit jellemzően a téli-tavaszi időszakban fejlesztő, különféle lombosmohák gametofitonján, zuzmótelepeken, de nyers talajfelszínen is megjelenő zuzmófaj. Az észak-amerikai kontinensen és Európában egyaránt elterjedt, de kis mérete és jellemzően téli megjelenése miatt ismert előfordulási adatait tekintve valószínűleg alulreprezentált. Magyarország területéről eddig nem volt ismert, börzsönyi, bükki és zempléni előfordulásai újak a hazai zuzmóflórára.

\section{REFERENCES}

Alstrup, V., Svane, S. and Søchting, U. (2004): Additions to the lichen flora of Denmark VI. Graphis Scripta 15: 45-50.

Aptroot, A., van Herk, C. M., Sparrius, L. B. and Spier, J. L. (2004): Checklist van de Nederlandse Korstmossen en korstmosparasieten. - Buxbaumiella 69: 17-55.

Chambers, S. P. and Purvis, O. W. (2009): Vezdaea Tscherm. - In: Smith, C. W., Aptroot, A., Coppins, B. J., Fletcher, A., Gilbert, O. L., James, P. W. and Wolseley, P. A. (eds): The lichens of Great Britain and Ireland. The British Lichen Society, London, pp. 958-961. 
Clauzade, G. and Roux, C. (1985): Likenoj de Okcidenta Europa. Ilustrita determinlibro. - Bull. Soc. Bot. Centre-Ouest 7: 1-893.

Coppins, B. J. (1987): The genus Vezdaea in the British Isles. - Lichenologist 19: 167-176. https://doi.org/10.1017/s0024282987000136

Czarnota, P. and Kukwa, M. (2009): Contribution to the knowledge of some poorly known lichens in Poland. III. Trapelia corticola and the genus Vezdaea. - Folia Cryptog. Estonica 46: $25-31$.

Diederich, P., Van den Broeck, D., Ertz, D., Signoret F., Aptroot A., Sparrius, L., JorDAENS, D. and SÉRUSIAUX, E. (2006): Contribution to the knowledge of lichens in northern France. - Bull. Soc. Nat. Luxembourg. 106: 53-62.

Giralt, M., Poelt, J. and Suanjak, M. (1993): Die Flechtengattung Vezdaea mit V. cobria spec. nov. - Herzogia 9: 715-724.

Gyalog, L. and Sí KHegyi, F. (eds) (2005): Magyarország földtani térképe, M=1:100 000. - Magyar Állami Földtani Intézet, Budapest. https://map.mfgi.hu/fdt100/ (accessed: 10.09.2017).

Kocourková, J. (2000): Lichenicolous fungi of the Czech Republic. (The first commented checklist). - Acta Mus. Nat. Pragae, Ser. B., Hist. Nat. 55: 59-169. (1999).

LENDEMER, J. C. and YAHR, R. (2004): Changes and additions to the checklist of North American lichens II. - Mycotaxon 90: 319-322.

LöKös, L. and FARKAS, E. (2009): Revised checklist of the Hungarian lichen-forming and lichenicolous fungi. (Magyarországi zuzmók és zuzmólakó mikrogombák revideált fajlistája). http://www.okologia.mta.hu/sites/default/files/MO2009_vegso_tordelt_pdfnek.pdf (accessed: 10.09 .2017$)$

PALICE, Z. (1999): New and noteworthy records of lichens in the Czech Republic. - Preslia 71: 289-336.

PYK ̈̈LÄ, J. (2006): Additions to the lichen flora of Finland. - Graphis Scripta 18(2): 41-48.

Santesson, R., Moberg, R., Nordin, A., Tonsberg, T. and Vitikainen, O. (2004): Lichenforming and lichenicolous fungi of Fennoscandia. - Museum of Evolution, Uppsala University, Uppsala, $359 \mathrm{pp}$.

Scholz, P. (2000): Katalog der Flechten und flechtenbewohnenden Pilze Deutschlands. - Schriftenr. Vegetationskunde 31: 1-298.

Smith, C. W., Aptroot, A., Coppins, B. J., Fletcher, A., Gilbert, O. L., James, P. W. and Wolseley, P. A. (eds) (2009): The lichens of Great Britain and Ireland. - British Lichen Society, London, $1046 \mathrm{pp}$.

Stepanchikova, I. S., Himelbrant, D. E., Kukwa, M. and Kuznetsova, E. S. (2011): New records of lichens and allied fungi from the Leningrad Region, Russia. II. - Folia Cryptog. Estonica 48: 85-94.

Svensson, M. and Westberg, M. (2010): Additions to the lichen flora of Fennoscandia. - Graphis Scripta 22(2): 33-37.

Svoвoda, D. (2007): Lichens of the central part of the Bohemian Karst. - Novit. Bot. Univ. Carol. 18: $15-52$.

TÜRK, R. and BERGER, F. (1999): Neue und selten Flechten sowie lichenicole Pilze aus den Ostalpen III. - Linzer biol. Beitr. 31(2): 929-953.

Verseghy, K. (1994): Magyarország zuzmóflórájának kézikönyve. - Magyar Természettudományi Múzeum, Budapest, 415 pp.

Wirth, V., Hauck, M. and Schultz, M. (2013): Die Flechten Deutschlands. Vol. 2. - Eugen Ulmer, Stuttgart, $1244 \mathrm{pp}$.

(submitted : 10.03.2018, accepted : 28.05.2018) 